\title{
Partly subsistent household economies and modern consumerism in the Namibian Kavango: Assets, income, expenditure and socio-economic stratification
}

\author{
Michael Pröpper, Thomas Falk, Stephanie Domptail, Laura Marlene Große \& \\ Benjamin Kowalski
}

\begin{abstract}
The Okavango Basin encompasses a wide range of ecosystems and, corresponding to its extension across Angola, Botswana and Namibia, a multitude of communities with diverse socio-economic co: Households in the rural and urban Kavango region of Namibia experience the effects of rapid global economic change, mostly indicated by the emergence of new markets for consumer goods, the replacement of traditional barter with cash economies, and the parallel and subsequent incentives of myriad new consumer items. Overall this process of increasing consumerism transforms the aspirations and economic strategies of formerly subsistent famers. Presenting ethnographic, qualitative and quantitative data on household incomes, expenses and assets, we will illustrate this process for the central Kavango. We will especially discuss the implications of clearly visible economic stratification for communities and the natural resource base.
\end{abstract}

Keywords: Commodification; consumerism; household inventories; modernity; Namibia; Okavango; social stratification; socio-economic baseline survey.

Abbreviations: NHIES $=$ National Household Income and Expenditure Survey 2009/10; TFO $=$ The Future Okavango; SEBS $=$ Socio-Economic Baseline Survey.

As economias domésticas parciamente subsistentes e o consumismo moderno no Kavango namibiano: ativos, renda, despesas e estratificação sócio-econômica.

Resumo: As famílias da região rural e urbana de Kavango na Namíbia experimentam os efeitos da rápida mudança econômica global, sobretudo indicada pelo surgimento de novos mercados para os bens de consumo, a substituição da tradicional troca de bens e serviços por economias de dinheiro e pelos incentivos paralelos e subseqüentes de inumeráveis novos itens de consumo. Em geral, este processo de crescente consumismo transforma as aspirações e estratégias econômicas de antigos agricultores de subsistencia. Apresentando dados etnográficos, qualitativos e quantitativos sobre os rendimentos, despesas e ativos familiares, vamos ilustrar esse processo para o Kavango central. Vamos especialmente discutir as implicações da estratificação econômica, claramente visível, para as comunidades e os recursos naturais.

Palavras-chave: consumismo; estoques domésticos; estratificação social; estudo de base sócio-econômico; mercantilização; modernidade; Namíbia; Okavango.

Received: 15 April 2013 - Accepted: 19 December 2013

\section{Introduction}

In the past, households across the Okavango basin in Southern Africa were strongly dependent on subsistence cropping, livestock keeping and extractions of resources from nature (Fisch 1999, 2005, Mendelsohn \& el Obeid, 2003, 2004). While today subsistence is still dominant in large parts of the basin societies, economies and household livelihoods are in the process of transformation. In the Kavango regions of Namibia households are increasingly using and depending on cash and are consuming goods such as cooking oil, shop food, artificial hair, plastic chairs, radios and cell phones. These goods have been manufactured and produced along global commodity chains and are being imported and traded in cash-based markets. It is reasonable to suppose that as such goods replace subsistence goods or items of material culture their use will lead to changes in household economies and cause a shift in household budgeting.

We shall refer to this process of global market integration as the advent of consumerism (Campbell 1987, Stearns 2001). Consumerism has been described critically as "the crass elevation of material acquisition to the status of a dominant social paradigm" (Princen et al. 2002). It can be seen as a historically and globally expanding process through which increasing numbers of people develop new desires (Belk et al. 2003, Stearns 2001) and attempt to achieve well-being (Mathews. \& Izquierdo 2009) through the consumption of objects (e.g. goods, energy, information) which were not needed for subsistence (Stearns 2001).

Consumerism is the most visible tip of the iceberg of modernity. Modern 'consumer cultures' - societies whose economic order systematically fosters consumer desire to acquire greater 
amounts of goods, information, etc. (Wilk 2006) with cash - offer a cornucopia of things, ideas and incentives for new lifestyles. As such, consumerism is rapidly transforming the social and economic world in the remotest parts of Africa (Hahn 2008). Studying the expansion of Chinese migrant traders, Dobler (2009) finds that in Namibian society "the consumption of western goods is gradually moving into the centre of majority ambitions".

Additionally, 'consumerism' describes the consequences of the widespread theory that increasing consumption of goods, information, energy, etc. is economically beneficial and necessary. Critics argue that the ecological externalities of consumerism (waste production, raw material and energy depletion, deforestation, etc.) are insufficiently considered in calculations of economic benefits (cf. Miller 2012, Princen et al. 2002, Wilk 1998). It is not only the increasing amount of goods but also the increasing amount of waste that makes this phenomenon highly salient in the Kavango regions.

Against this background, the acquisition of detailed knowledge about household economies is a crucial first step in understanding such processes of transformation. In particular, understanding the changing roles and importance of, and the meanings and values attributed to both imported and natural resources and ecosystem services within households seems to be a precondition for assessing future trends. 'Ecosystem services' is a broad term covering conditions and processes through which ecosystems produce benefits for people, such as drinking water, clean air, experiences of beauty etc. (Chan et al. 2012, Daily 1997). In the long run such knowledge about household economies and socio-cultural consequences may help in predicting how such interactions may change under different scenarios and what impact such changes may have for the environment.

A second, but equally important aspect of the advent of consumerism that we will target in this article is that of the potential social consequences, especially socioeconomic stratification, which become salient through the varying degrees of involvement of households in consumerism. Social stratification can be indicated by persistent inequalities in material situation, access to land, status and power (Saunders 1990, Weber 1964, 2010). As we will further outline below, additional inequalities in life experiences and opportunities (mediated by e.g. communication or mobility) can be found in Kavango (Fumanti 2002). The expansion of new cash-based markets, inciting all sorts of new household desires by promising new comforts, occurs in a competitive and problematic setting where a majority of people live in poverty or far below national and Western standards of living. In Kavango, as in Namibia and adjacent countries, there are widespread inequalities, poverty, and rapid migration, social security and related institutions are largely absent, as is any formal labour market, though there is a large subsistence farming and informal labour sector (Kapaana 2007, National Planning Commission 2003, 2003/2004, 2012). The degree of inequality in the distribution of family income in Namibia, expressed by a 2010 Gini-Coefficient of 0,59 , is still among the highest in the world (Isaacs 2012) ${ }^{1}$. Despite the fact that development and the leveraging of poverty and inequality are national goals (Republic of Namibia 2004) we must take into account that during the transitory phase of the advent of consumerism, social stratification is a problem.

The interdisciplinary research project The Future Okavango (TFO) assessed social and economic household-related data in order to gain a basic understanding of relations between resource use and ecosystem services. Within TFO such data were collected with multiple methodologies and involved at an early stage with a SocioEconomic Baseline Survey (SEBS) employing in particular semi-structured interviews. The survey captures aspects of demography, livelihood and resource use strategies, as well as wealth indicators. We have complemented this rather static data set with broader qualitative assessments of socioeconomic change and transformations.

To gain a deeper understanding we will present and discuss both the data and the challenges involved in producing a sound household income assessment, and present results of our household income, expense, and endowment analyses. To describe the underlying constraints and challenges that single households experience in the face of the advent of modern consumerism is an additional task

${ }^{1}$ See also https://www.cia.gov/library/publications/the-world-factbook/rankorder/

2172rank.html of this article. Ultimately what these data document and illustrate is the strong social and economic stratification of the Kavango society under increasing consumerism. We will envisage and discuss the multiple potential implications of these findings for future studies.

\section{Assessing household economies: Challenges and methodologies}

To determine the main factors of household economies in terms of incomes and expenditures in a setting of (mainly rural) subsistence, with interlocutors struggling with poverty and poor literacy, poses a methodological challenge. The accuracy of information about figures and amounts often relies on the memories of farmers, which, especially in the oral assessment of yields, field sizes, labour times, distances, measures and amounts, often prove to be deficient. Many transactions within and among households occur without reference to a universal measure such as cash, relying instead on barter, and often there is no time- or bookkeeping for these activities. Furthermore, transaction costs and externalities of trades are often not taken into consideration or are not being balanced. The reliability of memories is especially problematic where monthly or annualized data are being assessed through retrospective interviews, or where such data are being annualized. Observations are a vital complement to an assessment relying purely on oral data. However, observations can only cover a limited spatial and temporal context and are very time-consuming. Hence, such concurrent data can only be assessed in a limited manner - in comparison to questionnaire-based surveys.

A second problem is the stratification of society, on which we will further elaborate below. Under circumstances of strongly diverging and multidimensional social strata the calculation of averages is certainly helpful for coarse-grained comparisons, e.g. as a supra-regional indicator. In addition, in explaining actual land user behaviour, we further consider that actors' individual positions within a given context certainly impacts on their real-life choices. Equally important is the fact that households themselves are internally stratified and gendered accumulations, often guided by the rules and norms of kinship and seniority. 
Accumulated household figures can mask the individual aspirations and strategies of actors, hence ethnographic details can be used to shed light on such factors.

Under these circumstances it was imperative for us to first gain a solid ethnographic understanding ${ }^{2}$ of diverse household income activities and transactions in 2011 and 2012. We subsequently proceeded in two stages. A smaller sample of stratified households $(n=13)$ residing within the core site of Mashare was thoroughly interviewed about their income and expenses in 2011. Additionally, to gain a broader regional picture, a similar survey in three schools - of which two were in the rural vicinity of the capital Rundu, $(\mathrm{n}=80)$ and one was in Rundu $(\mathrm{n}=18)$, with 98 learners of grade 10-12 - was undertaken. It was hypothesized that these literate young adults would be suitable respondents for a written survey since they would have precise insight into their household economies (Henry \& Macbeth 2004). The urban portion of the sample $(\mathrm{N}=16)$ may be biased towards households who are able to afford a higher education. The school survey also contained a qualitative section about consumption habits, desires and perspectives on the future of the young generation.

At the core of the activities of the broader social science team of TFO was the jointly designed survey. Data collection was undertaken in November and December 2011 in the core research site west of Rundu. A total of 506 households were counted in an area encompassing 5 villages, of which 292 households were selected randomly. The survey covered 1812 individuals $(54.41 \%$ female, $45.59 \%$ male) of these households. The survey was executed with the assistance of trained interviewers, and contained sections on demography, household composition, households' consumption, households' living situation, farming activities, strategies and preferences, income, expenditure and subsistence.

As outlined above, these data offer a good basic overview of a current socioeconomic status quo in a particular rural area. We compare the results with broader national statistics of the National

${ }^{2}$ The authors draw on almost a decade of work on the Kavango between 2002 and 2012 including several years of on-site fieldwork. Work took place in the central inland Kavango region, in and around Rundu, the regional capital, as well as the riverside region west of Rundu, The Mashare area of TFO research.
Household Income and Expenditure Survey 2009-2010 (Namibia Statistics Agency 2012a, b, National Planning Commission 2010) and the Namibia 2011 Population and Housing Census (National Planning Commission 2012). These national data sets contain regional comparisons of urban versus rural contexts, however, such comparisons are in many cases only published for the national level. This means that using e.g. a national urban vs. rural stratification may rather mask regional peculiarities.

To gain a better idea of local consumption realities, the differences in household assets were inventoried, with 39 inventories in five villages in TFO's Mashare research area. Households were chosen opportunistically, with the aim of representing the breadth of stratification in the different villages. Thus, households which were known to be wealthy or very poor, as well as those in the economic mid-range, were deliberately selected. Respondents were interviewed about their assets with a list of consumer items, sources of cash, origins and histories of acquisition. This survey was accompanied by qualitative interviews on their perceptions of transformations and disparities.

Furthermore food consumption habits of 12 stratified households - chosen according to the same criteria as mentioned above - were assessed with a variety of methods including recall interviews, systematic observations and food diaries.

Our approaches are complementary, and chosen in order to draw a more concise picture of current incomes in an increasingly consumerist society. After outlining the socio-political setting, we will present in the following sections descriptions and analyses of household assets, incomes and expenditures.

\section{The Kavango in transformation}

The Kavango region in the Northeast of Namibia, consisting of two parts Kavango West and Kavango East - is a sub-humid region of southern Africa. In total it is slightly larger than Switzerland, and in 2012 was home to about 222,500 people and 36,400 households. The average household size was six persons, and the sex ratio of the population (males/females) was 0.88 (National Planning Commission 2012). The region has experienced a strong population growth over decades. Between 1943 and 1996 the population increased almost tenfold from 15,500 to about 150,000 (Pröpper 2009). Using own census results Pröpper found an ongoing natural population growth of at least $1.5 \%$ (2009).

Casting a look at the Kavango in the context of transformations at the national level, we find that the Namibian society in general suffers from a highly unequal income distribution and systematic differences with regard to food consumption (Namibia Statistics Agency 2012a). The last National Household Survey revealed that especially when it comes to ownership of and access to selected goods like radios, television, cell phones, motor vehicles and kitchen equipment the Kavango fell far below the national average in all categories (ibid. 2012). The average annual per capita consumption (PCC) is among the lowest in the country and is skewed towards women. With a PCC of $2757 \mathrm{~N} \$^{3}$, women in Kavango in particular have the lowest in Namibia. The food consumption ratio $(\mathrm{FCR})^{4}$ - an indicator of poverty - for Kavango indicates that $50 \%$ of the households have a FCR of above $60 \%$, while $8 \%$ spent almost all of their resources on food. The ratios are especially high in rural areas.

Two thirds of the Kavango population reside in the rural parts, while one third lives in the urban areas of Rundu, the only major town, as well as in some smaller towns. Town and country cannot be perceived as dichotomous or opposing parts but rather as strongly interconnected and woven together by circles of migration, kinship-based exchange, and consumer goods transactions (Greiner 2008). Networks of families circulating goods, labour and money are very common. Rural households produce goods for town counterparts who, in exchange, may for instance host the schoolchildren of their relatives. Options for rural households to engage in markets or to work for financial capital are limited, and cash comes primarily from off-farm labour, pensions, the sale of natural resources and livestock,

${ }^{3}$ About 350 US\$ in 2012 .

${ }^{4} \mathrm{FCR}$ means the percentage of the total household consumption accounted for by food and beverages. If the food consumption is higher than the non-food consumption then the FCR is above $50 \%$, and vice versa. High FCR thus means that households use most of their resources for food consumption and lack the means to satisfy needs other than food. 


\section{Ownership of selected assets}

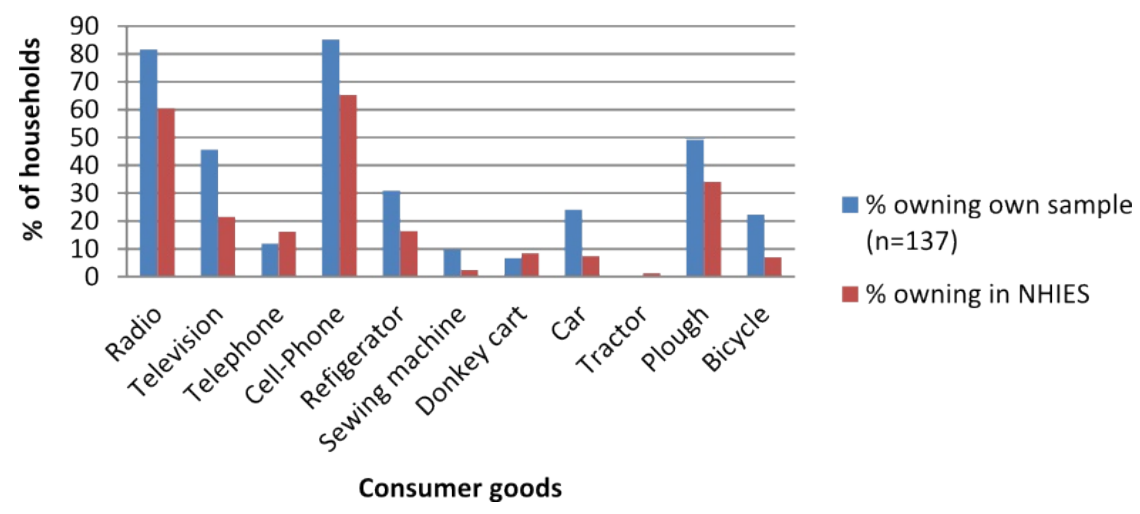

Fig. 1: Ownership of selected assets.

remittances, and reciprocity within ruralurban networks (see Fig. 3). As we will further elaborate below, Kavango households usually diversify their livelihood strategies. For many people subsistence farming plays a major role in providing the household with basic staple food. Salaries, business activities, pensions and remittances are important cash income sources (National Planning Commission 2003/2004).

Approximately four-fifths of the regional population makes a large part of their livings from cropping (Mendelsohn \& el Obeid 2003, National Planning Commission 2003, Pröpper et al. 2010). Subsistence farmers depend on rain-fed non-irrigated agriculture on rather infertile and sandy soils, mainly cropping millet, maize and sorghum (Pröpper. 2009). Households operate mostly on communal state-owned land and depend on diesel-engine water pumps (National Planning Commission 2003, 2010) (see Fig. 1+2). Cropping is a deeply rooted cultural activity that enables households to subsist largely without large cash investments. Despite small yields and their limited contribution to the monetary household budget (see Fig. 3) the cultivation of crops is perceived as the most important source of income and security against food shortage.

Next to crop-based subsistence, people hold cattle. Cattle are mainly used for draught power, as capital and status but not primarily for marketing purposes (Falk 2008, Pröpper 2009). Cattle and inkind payments continue to play an important role in informal labour transactions as well as in the fine-system of traditional law, in which heads of cattle confiscated are a measure of the severity of a crime (Hinz 2010, Kaundu 2002, Sikerete 2006). Farmers produce most of node of entrepreneurial activities. Urban a transfrontier region, and becoming a life in Rundu resembles a beehive of cash-based commercial development. The town offers increased access to the discourses of regional and national newspapers and television. It is emerging as a hub of trans-border commerce with Angola on the other side of the river. Supermarkets, fashion shops, furniture and electronics stores, cash loan agencies, and private medical clinics have mushroomed in only a decade.

Poverty, inadequate social security systems, and unemployment are current challenges. Poverty is a relative category, however, many of our informants perceived themselves as vulnerable within the social fabric and as inextricably enmeshed in ruhepo ruetu, 'our poverty'. The figures of NHIES showed a decline over the whole of Namibia of numbers of poor and severely poor households between 2003/04 and 2009/10. In $200919 \%$ of households were considered as poor (compared with $28 \%$ in 2003), and $10 \%$ of households were severely poor (14\% in 2003) (Namibia Statistics Agency 2012a). While a positive trend can also be observed in the Kavango regions, they are still the most impoverished districts of Namibia, with $43 \%$ of their households being poor and $24 \%$ being severely poor (Namibia Statistics Agency 2012b). The population and housing census revealed that in 2011 three quarters of Kavango households had no toilet and one fifth had no electricity for cooking or lighting (Namibia Statistics Agency 2012a) (see Fig. 2).

At our research site no more than four percent of the households are electrified. Our survey data show that $62.54 \%$ of the

\section{Households by selected main housing indicators (NHIES 2012)}

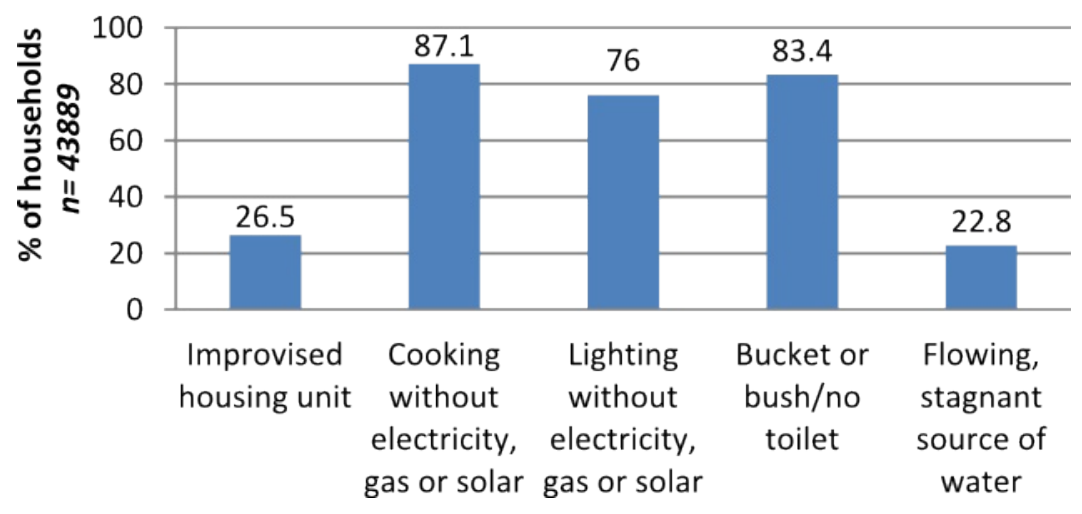

Fig. 2: Households by selected main housing indicators NHIES 2012. 


\section{Average available household cash income (SEBS; $n=292$ ) share per income source}

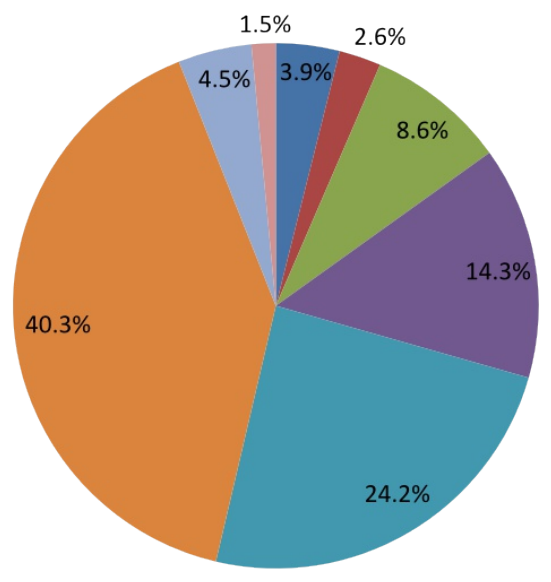

Fig. 3: Average available household cash income in SEBS.

households mainly depended on water from the river while $21.99 \%$ used public tabs and $8.25 \%$ used boreholes with a closed tank. Only a minority of $11 \%$ used insurance products to mitigate typical risks. According to NHIES the unemployment rate was $23.0 \%$ in 2009/10 Namibia Statistics Agency 2012a, National Planning Commission 2003).

In the face of poverty and unemployment, segregation is evident between a few very rich entrepreneurs, a growing urban middle class, and a vast majority of impoverished urbanites living in slum quarters scattered around the town and working in an informal sector (Mendelsohn \& el Obeid 2003).

The increased access to markets and the greater availability of consumer items open up a field of tension and constant movement between societal strata and spatial patterns. To be able to live in a town, access to cash is necessary. There are incentives to exploit and commodify natural resources for urban populations who feel less dependent on the long-term maintenance of ecosystem service provision, as can be observed in the widespread problem of illegal cutting of high-value timber. This often happens at the expense of rural communities. In other cases it opens new alternatives to the clearing of forests and provides incentives to maintain the natural vegetation. An example is the growing market for thatch grass.

\section{Household assets, income \& expenditure}

The Kavango society is characterized by a high degree of subsistence, and discriminating between assets and income is a challenge. We will define income as the sum of all the wages, salaries, profits, interest payments, rents and other forms of earnings received in given short- or medium-range intervals of time (Case et al. 2009). Assets, though also being replaced in flows or intervals, are rather long-term household possessions such as fields, homesteads, a car, a refrigerator etc. Livestock is certainly an asset, given the long-term ownership and low rate of selling that is practised, however, cattle can also be sold to generate income.

\section{Assets}

Land is one of the main assets of the rural population. The Kavango regions are classified as communal areas, where the land is vested with the state and administered in trust of the communities (Falk 2008, Republic of Namibia 2002). Land is allocated by traditional authorities. A communal land board approves the allocation and resolves upcoming conflicts (Republic of Namibia 2002). Our governance analysis did not reveal any alarming signs of institutionalised discrimination with regard to land allocation. The distribution of land ownership is difficult to assess as respondents hardly knew the size of their fields. More than two thirds (66.02\%) of farming households own one field, while less than one third $(28.91 \%)$ have two main fields. We suspect land holdings to be as unequally distributed within the community as any other asset. The size of the area under cultivation strongly depends on the means of production available to the household. Without even an ox and a plough, poor families will only cultivate, and therefore own, much smaller fields.

Kavango households are differently endowed with another major visible asset - housing. While urban houses of people living mainly off jobs/salaries are mainly built from stone with corrugated iron roofs, the peri-urban and rural homesteads are largely built with materials extracted from nature, like wooden poles, clay, and grass. Our SEBS revealed that in Mashare $76.71 \%$ of the houses are composed of wood and clay and $72.07 \%$ of the roofs were built from thatch, while only $26.21 \%$ were covered with corrugated iron. Among the rural households interviewed, $87.67 \%$ were practicing cropping or gardening, while only $12.33 \%$ were not living off subsistence farming. Millet (86\%) Maize (79\%) and Sorghum (64\%) were the main staple crops planted. Within this sample there was almost no use of fertilizer, pesticides, or manure, and $96.43 \%$ of the fields were not irrigated. In addition, households around Mashare directly extract ecosystem goods. Between 60 and $90 \%$ of all households use fish, roots, fruits, nuts, thatch grass, reeds, construction wood, stones and clay, and firewood on a regular basis. Almost all households around Mashare (97\%) use wood as their main fuel and energy source. In comparison, NHIES figures for the Kavango region, including the partly electrified towns, indicate the use of wood for cooking by $84.3 \%$ of households (Namibia Statistics Agency 2012a).

Livestock is a highly valued asset used for multiple purposes. Livestock means status, but it is also a form of stored capital that can be used as a security in cases of need and emergency (Pröpper 2009). Livestock sales make an important contribution to the average household monetary incomes (see Fig. 3), even though we found that offtake numbers are still relatively low compared to commercial farmers. NHIES figures for the Kavango region show that less than half of the population's households $(43.5 \%)$ own cattle, $33.6 \%$ own goats and $61.1 \%$ own poultry (Namibia Statistics Agency 2012a). Interestingly, there is no 


\section{Kavango households by main source of income (NHIES 2012, n=43889)}

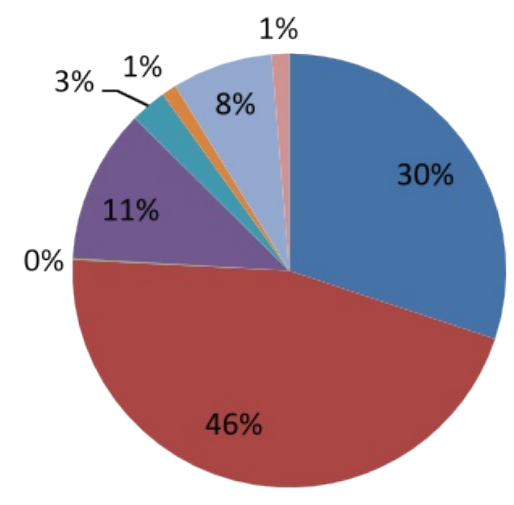

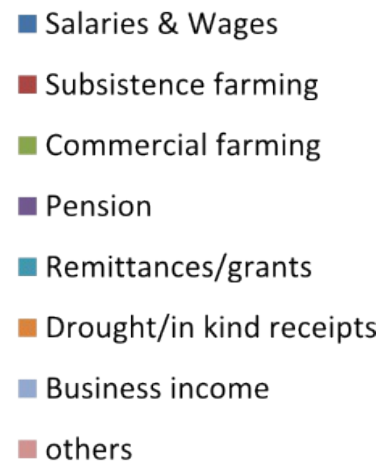

Fig. 4: NHIES Kavango households by main source of income.

real difference in livestock ownership between households with different education levels, meaning that livestock remain a highly valued source of status and capital for more educated people (ibid.). At our research site the situation is slightly different, as cattle are highly valued as draught power. However, it is crucially important to bear in mind that while two thirds of households own livestock, $33 \%$, or one third of households, do not own any livestock.

For this remaining third, owning one ox would liberate them from having to rent oxen for ploughing. The ownership of even small numbers of livestock means a certain wealth and reduced vulnerability against indebtedness, serious misfortune, disease and other unforeseeable but costly events. Livestock ownership is unequally distributed, with about half of all cattleowning households possessing a total of around $10 \%$ of all the cattle (with between one and 10 heads each) while the other half possess the remaining $90 \%$.

Lastly we want to turn the attention to some exemplary 'assets of modernity', which symbolize the endowment of households with modern items of consumerism. Figure 1 condenses data from the 137 household inventories, integrating the 98 school surveys and 39 household inventories in the rural and urban context. Consequently the sample is a broad overview that does not only depict the rural area, and can therefore be compared to NHIES data. It illustrates the increasing importance of certain goods in households - especially radios, as the main means of mass communication, but increasingly cell phones, for individual communication, and television are also important parts of a growing number of production activities) state their main source of income. According to the results most of the Kavango households (43\%) consider farming to be their main source of income (see Fig. 4$)^{5}$. Twenty two percent depend mainly on salaries and wages, and $13 \%$ rely primarily on pensions (Namibia Statistics Agency 2012a). The national proportion of wages and salaries has in fact increased since 1993/1994 from 23 $\%$ to $48 \%$ (National Planning Commission 2010).

The total tradeable household budget gives important insight into the relative proportions of income sources (see Table 1). Nevertheless, due to the diversity of strategies and the diversification of sources of incomes, such a clear-cut separation is not an adequate picture of the actual situation. Our data show that income sources are diverse and overlapping. Among the 13 households providing the income sample data and the additional 98 households represented in the school sample, only a very few households relied on one or two sources of income alone. Additionally, the mixes of income types were very broad.

In 2009, according to the NHIES, the annual income of a Kavango household was $36,740 \mathrm{~N} \$(4,899 \mathrm{US} \$)^{6}$ and the per capita income was $5,682 \mathrm{~N} \$(75,760 \mathrm{US} \$)$ (adjusted value 6,766N\$/ 902US\$) ${ }^{7}$ (Namibia Statistics Agency 2012a). In 2011, the SEBS revealed a gross annual

In the NHIES respondents were asked to

Table 1: Total tradable household budget (cash income and monetary value of

\begin{tabular}{lrrrrr}
\hline \multicolumn{1}{c}{ Variable } & Obs & \multicolumn{1}{l}{ Mean } & Std.Dev. & Min & \multicolumn{2}{c}{ Max } \\
\hline Remittances & 221 & 326.241 & 899.647 & 0 & 8000 \\
Transfers & 221 & 1219.005 & 2209.278 & 0 & 9000 \\
Pensions & 221 & 3765.611 & 5397.600 & 0 & 48000 \\
Business & 221 & 1990.045 & 8747.908 & 0 & 96000 \\
Salary & 221 & 9813.742 & 29323.770 & 0 & 288036 \\
Livestock own & 221 & 22880.770 & 57706.490 & 0 & 633100 \\
Livestock & 221 & 1818.778 & 5662.657 & 0 & 61500 \\
sell/exchange/donate & 209 & 5722.500 & 22457.940 & 0 & 255000 \\
Natural resource harvest & 221 & 1879.371 & 2380.624 & 0 & 19990 \\
Agricultural harvest & & & & & \\
\hline \hline
\end{tabular}

${ }^{5}$ NHIES does not currently clearly discriminate between urban and rural incomes on a regional level, and unfortunately we are not aware of any surveys yet assessing income or expenditure figures for the urban sector only.

${ }^{6}$ Calculating an average exchange rate for 2009 of $7.5 \mathrm{~N} \$$ to $1 \mathrm{US}$

${ }^{7}$ The adjusted per capita income - in contrast to the per capita income - discrimimates between the consumption of adults and of children (National Planning Commission (2010): Namibia National Household Income and Expenditure Survey 2009/2010 Preliminary Results. Windhoek: Republic of Namibia, RoN.). 
household disposable income ${ }^{8}$ of 22,855 N\$ (US\$ 3,192) and a per capita income of 3,682 N\$ (US\$ 514) ${ }^{9}$ for the strongly subsistence-based community of Mashare.

Accumulated average income figures and statistics describe an average type of household that in reality rarely exists. In fact, the situation is more clearly illustrated by discriminating between farming and cash sources of income.

\section{Farming subsistence incomes and consumption}

As outlined above, large portions of society see farming as their main source of income. In our study area, selling or trading of crops contributed on average only $0.44 \%$ to the overall household budget (Fig. 3). Even if one values the harvest according to market prices and in this way includes the subsistence income, the contribution of cultivation to the household budget is not more than $7.08 \%$. These figures clearly do not reflect the perceived importance of agriculture for the surveyed population.

We conducted an agricultural yield assessment in order to gain a better understanding of the subsistence income in our study area (Gröngröft \& LutherMosebach 2012). The mean yield of millet per household was found to be very low, with only $161.2 \mathrm{~kg} / \mathrm{ha}^{-1} .^{10}$ This figure confirms findings made in an inland Kavango settlement (Pröpper 2009). Those households without livestock or additional sources of cash income are at times particularly vulnerable to food shortages, and have no additional yields to sell.

Taking into account that this harvest does not provide sufficient calories to satisfy the most basic physiological needs of a household, we looked more deeply into subsistence livelihood strategies. In the SEBS we also asked about the composition of meals eaten over the

${ }^{8}$ Household production, including sale/ exchange/ donation values, excluding subsistence income.

${ }^{9}$ Based on average exchange rate for 2011 of $7.16 \mathrm{~N} \$$ to 1 US\$ (www.oanda.com).

${ }_{10}$ This yield correlates with the Mahango biomass $(=$ cobs + stalks) of the fields (yield $=$ 0.0072 biomass $+0.4426 ; \mathrm{R}^{2}=0.357$ ), however, the scatter plot indicates a strong variation of grain yield between samples of identical biomass Gröngröft \& LutherMosebach (2012). TFO: Draft Report on the Yield Assessment Campaign 2012. In. Hamburg: Institute of Soil Science.) previous 30 days. The results show that on average during that period fish from the river was eaten on 8.91 days, while meat was consumed on 3.54 days.

\section{Cash incomes}

The data collected in our various surveys confirm that cash is a highly desired type of income that functions as a complement to household income from subsistence farming. Many households have diverse and overlapping sources of cash income such as salaries and wages, remittances, pensions and transfers, and business income.

Figure 4 illustrates that for the whole Kavango region salaries are the second most important source of income. Figure 3 indicates that for our SEBS sample on average salaries even contributed the largest share to household budgets. At the same time, our survey revealed that only 56 respondents receive salaries from casual work and only 77 people report having a permanent job. This shows that only a few benefit from salaries but that as soon as they manage to get a job they are much better off than their fellow community members.

Forty-one households report having a business income. Approximately half of them selling traditional alcohol. Observations and interviews confirm that many traditional bars operate without profits and are often owed considerable sums by people suffering from alcoholism (Vissers 1997) who constantly consume alcohol on credit without paying back their accumulated debts.

In SEBS we find that very small percentages of households profit from large mean per capita cash income contributions in the cases of e.g. commercial farming $(111,483 \mathrm{~N} \$ /$ 13,995 US\$) rental income $(28,724 \mathrm{~N} \$ /$ $3,606 \mathrm{US} \$$ ) or interest from investments $(77,460 \mathrm{~N} \$$ / 9,724US\$). At the same time the average annual per capita income from subsistence farming - explicitly a main source of income for one third of the population - is $6,533 \mathrm{~N} \$ / 820 \mathrm{US} \$$.

Figure 3 shows that sales of livestock appear to be the most substantial contributions to agricultural incomes, while the income from crop-sale is rather small. Again we would like to emphasize that livestock are also a form of cultural capital in Kavango. Farmers in our sample do not practice commercial livestock management. ${ }^{11}$ Livestock is most often sold in cases of immediate cash need. Only wealthy farmers with large herds also sell without being forced to (Falk 2008, Pröpper 2009).

In general, households that are able to rely on salaries, business activities and remittances for their income are better off and less vulnerable.

Over the six month period prior to the SEBS, significant amounts of remittances are an exception. On average, remittances contribute less than two percent to the household budget (Fig. 3). Approximately 23 per cent of the surveyed households receive sometimes several different and temporally independent types of remittances. Two third of them (42 households) enjoy monetary support. Inkind remittances such as millet or maize are another important source of income. In 22 cases $(33 \%)$ such contributions consisted of one $25 \mathrm{~kg}$ or $50 \mathrm{~kg}$ bag of of maize, in only three cases were these inkind remittances considerably larger, while the rest consisted of small items like soap or a loaf of bread.

Another form of income that may impact household budgeting - especially in terms of provision with financial capital - is that of cash loans. While in the urban setting cash loan agencies are becoming more and more evident, we did not find cash loans to be a major source of financial capital in the rural setting.

In sum, these findings indicate that additional cash incomes serve to fulfil new desires, and impact upon the perceived importance of subsistence. The NHIES also found that people who receive salaries or remittances engage in more cash transactions than people who rely on subsistence farming or receive pensions (National Planning Commission 2010).

\section{Expenditures}

Investigating household expenditures in a largely subsistence-oriented economy requires careful considerations about what can properly be considered an expenditure. Do we only calculate monetary expenditures, or include the costs of extraction from common natural resources? Can the collection and burning of firewood be interpreted as a type of expenditure? We do not attempt to

${ }^{11}$ Nevertheless, an increasing influx of large cattle herds is observable, especially in western Kavango, creating tensions with subsistence farmers Steinmann, D. (2004). Cattle breeders are a clever species. In, Economist (pp. http://www.economist.com.na/2003/2021 nov/2 011-2021-2003.htm access: 2025.2008.2004). Windhoek. 
provide an exhaustive list of types of expenditure for subsistence economies, but rather present a number of informative indicators.

Households in Kavango use several types of capital in the exchange for the items they need. The assessment of household expenditures nicely illustrates the transformation of household economies. Table 2 shows the main types of expenses as they were recorded during the school survey.

We discriminated between urban and rural households in order to compare household market activities (see Fig. 5). We observe that urban households benefit from lower transaction costs in accessing markets and basic goods such as water or fuel, which are, in the town, only supplied against cash payments. It becomes apparent that urban households also have other opportunities to save capital or insure themselves, and also to support relatives. Furthermore, many expenditures which require cash are also borne by rural households. They buy staple food and pay for transport or health services. But even rural households spend money on goods that do not merely satisfy their most basic needs. Judging by the amount spent, telecommunication (cell phones and user fees) are seemingly as important as spending on beauty products such as artificial hair.

Again, it would be desirable to quantify amounts of expenditure for certain types of expenses. Through the SEBS we have collected expenditure figures which fall into roughly the same categories we used in the school survey. Again, informants were asked for their average monthly cash expenditure for certain expenses groups (see Table 2). In the rural area around Mashare, transportation, repaying of credits and the consumption of alcohol in shebeens seem to be the most important spending categories. We estimated an average monthly household expenditure of $1,607.30 \mathrm{~N} \$$, with a high standard deviation of 2,256.55. ${ }^{12}$

We complemented the survey data with a more in-depth assessment of 13 households which were closely interviewed and questioned. We have drawn a stratified sample that includes different wealth groups as well as urban

\footnotetext{
${ }^{12}$ Both in the school survey and in the SEBS some informants had problems with the estimation of certain types of aggregated expenses (e.g. expenses for house renovations), especially on a monthly or yearly basis. These figures - but only these - should therefore be treated with care, and provide only a rough idea of the situation.
}

Table 2: Types of monthly household expenditures.

\begin{tabular}{|c|c|c|c|c|}
\hline Variable & Obs & $\begin{array}{c}\text { Average } \\
\text { monthly } \\
\text { household } \\
\text { expenditures }\end{array}$ & $\begin{array}{c}\text { Share of total } \\
\text { average } \\
\text { household } \\
\text { expenditures }\end{array}$ & Std. Dev. \\
\hline School fees & 287 & 59.15 & 3.50 & 140.39 \\
\hline Water fees & 253 & 10.16 & 0.60 & 46.84 \\
\hline Social networks & 290 & 37.67 & 2.23 & 109.06 \\
\hline Transportation & 290 & 283.73 & 14.14 & 340.43 \\
\hline Medical care/ hospital & 288 & 77.85 & 4.61 & 160.12 \\
\hline $\begin{array}{l}\text { Support of family members } \\
\text { (remittances) }\end{array}$ & 263 & 118.13 & 7.00 & 651.99 \\
\hline Shebeen/ drinking and tobacco & 290 & 312.94 & 18.54 & 345.68 \\
\hline Electricity & 256 & 16.11 & 0.95 & 90.71 \\
\hline Communiaction/ Airtime & 283 & 91.97 & 5.45 & 123.39 \\
\hline Insurance & 256 & 72.36 & 4.29 & 373.78 \\
\hline Taxes and Fees & 255 & 102.92 & 6.10 & 637.72 \\
\hline Maintenance & 257 & 39.16 & 2.32 & 99.93 \\
\hline Rent & 261 & 40.35 & 2.39 & 106.02 \\
\hline Savings & 267 & 241.03 & 14.28 & 433.78 \\
\hline Repaying of credits & 288 & 211.04 & 12.50 & 262.88 \\
\hline Traditional taxes and fees & 284 & 2.03 & 0.12 & 4.56 \\
\hline Payment to traditional healers & 255 & 16.31 & 0.97 & 50.53 \\
\hline
\end{tabular}

and rural households. Figure 6 illustrates the types of expenditures most widely shared within this sample with different colours. Again we can see that shopbought food, health care, education, church donations and clothing are types of expenses that all households share. Slightly less dominant are expenses for transport, communication, taxes and support of relatives. Still, more than half of the households $(n=7)$ buy maintenance materials, repay debts, save, or spend money on alcohol or beauty products. All but the urban households rely on subsistence production of cereals, but their consumption differs according to the household size. ${ }^{13}$

The expenses for shop-bought food as

${ }^{13}$ While all households except the urban depend on home production of cereals, amounts consumed differ according to household size and the estimations of the persons doing the cooking about how long existing supplies will last. As a rule of thumb it can be supposed that around half a cup (ca. $300-500 \mathrm{~g}$ ) per person per day is being onsumed $(=15$ cups per month $=$ ca. 0.3 bags $)$. well as the frequencies of shop visits differ strongly, with a minimum of $280 \mathrm{~N} \$$ and a maximum of $2,000 \mathrm{~N} \$$ (mean $=745 \mathrm{~N} \$$ per household). Average monthly expenses for health care are relatively small (mean $=34.68 \mathrm{~N} \$$, $\min =5 \mathrm{~N} \$, \max =50 \mathrm{~N} \$$ )

A trip to town and back costs about $50 \mathrm{~N} \$$ and households invest on average $196.50 \mathrm{~N} \$$ per month.

Expenses for telecommunication are highly stratified. Within 11 households using cell phones at all, 49 persons already possess a cell phone (see above) which is not only a means of communication but also a modern statussymbol. Nevertheless, household expenses on air-time differ greatly, between $50 \mathrm{~N} \$$ and $2,500 \mathrm{~N} \$$ per month. Only people with extra cash income actually use their cell-phones regularly to make calls, others only use them to receive calls.

While expenses on clothing are more widespread among households, the monthly average of about $45 \mathrm{~N} \$$ is far 


\section{Rural/Urban Types and Shares of Expenses in School Survey}

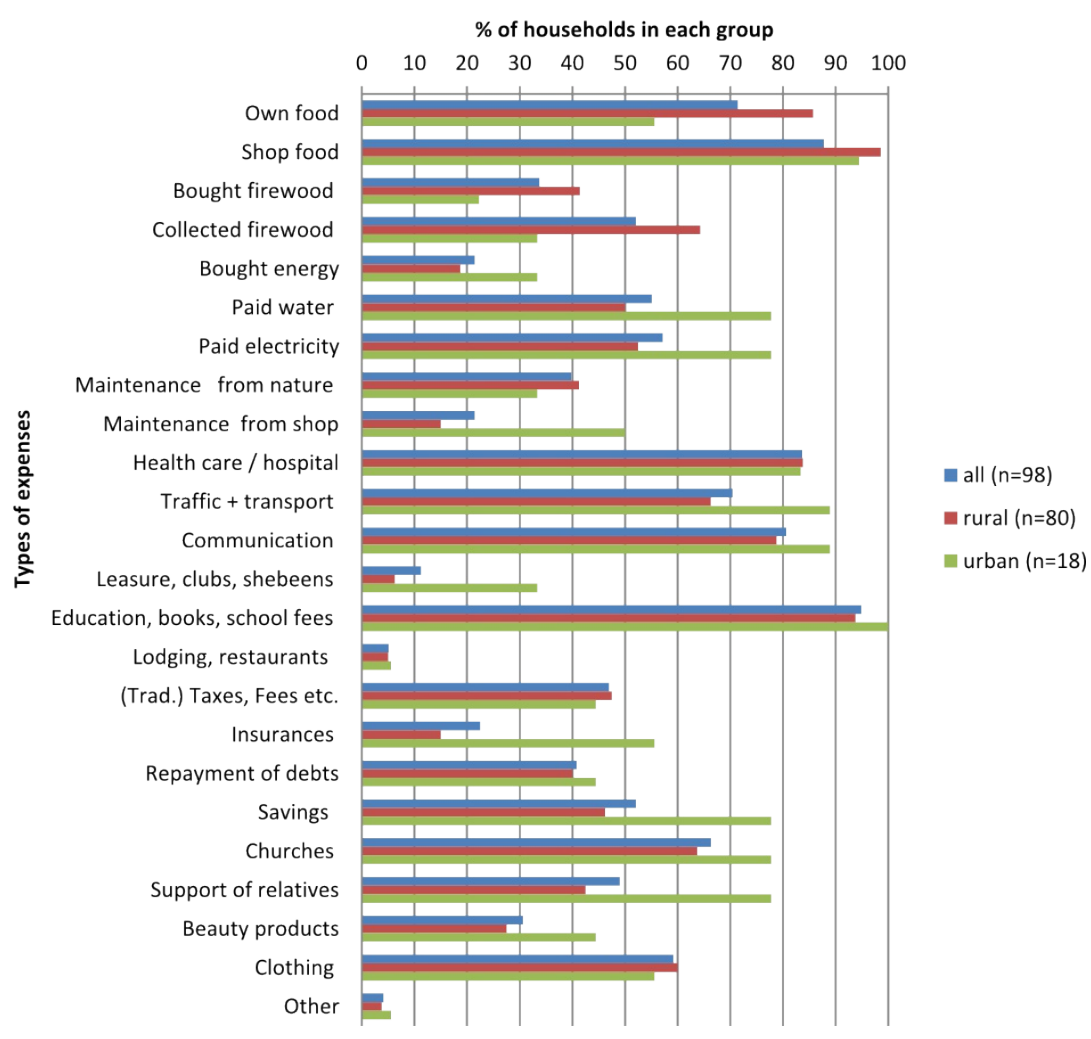

Fig. 5: Rural and urban types of expenses.

below the average for the six households who are able to expend a monthly $178 \mathrm{~N} \$$ on beauty products, mainly hair extensions.

The assessment reveals that households collect about 1.6 bundles of firewood per day. Firewood, which is becoming increasingly scarce close to the settlements, is regarded as common property and is collected in the communal forest further away from the river.

For other types of widespread expenses, like house-maintenance materials from shops, remittances, or expenses related to alcohol and clubs, it is impossible to reliably quantify averages, as respondents struggled to give estimates.

\section{Expansion of consumerism and asset histories}

To gain a rough idea of the spatial and temporal expansion of consumerism and market integration we recorded information about visible enterprises along a $60-\mathrm{km}$ stretch of road between Rundu and the Mutompo inland research area on multiple occasions between 2002 and 2008 (Falk 2008, Pröpper 2009). Comparing the data between 2005 and 2008 reveals the development of several new enterprises, like car repair shops, brick-makers and even one kindergarten. The number of grocery shops more than doubled during this period, from 14 to 31 . Furthermore, the number of traditional businesses offering commodities like fruits, grass, poles, firewood, and crafts increased by $60-80 \%$. Among all economic activities, by far the most common and fastest growing were shebeens, places of entertainment and alcohol consumption, where villagers often drank large quantities of alcohol. There were three times more shebeens than any other enterprise: a total of 126 in 2008.

A second way to gain an idea of the expansion of goods within household economies over time is through asset histories. During the inventorying of a stratified sample of rural households assets, we asked for the time of acquisition for each asset. We then sorted and compared their temporal 'points of entry' into households' cycles. There appears to be no fixed pattern of historic pathways of acquisition, but certain clusters of items are commonly acquired in a row.

The poor households in particular, most with no cattle, invested in tools, buildings, kitchenware and also the comfort of western sleeping facilities at an early stage. These items were followed in time by items like plastic chairs and fine clothing and shoes, which indicate a certain modest status. Poor households rarely have a bank account or modern items of transportation and communication. In fact, not possessing a radio or a cell phone is a strong indicator of poverty and low status, hence even the poorest people try to get hold of both of these items.

In contrast, households that can be considered moderately wealthy initially purchased the same basic goods, but at some stage began acquiring cattle or a car, or electricity for a refrigerator, or a generator. In these cases, possessing livestock and modern consumer goods like cell phones, plastic furniture, and radios is the norm.

Wealthy households certainly acquired all the basic items mentioned in the other groups. But their patterns of acquisition differed from an early stage. They often had an early opportunity to use electricity and cash income. Cash was invested, especially in cattle and/or transport, or in a business like a shebeen. In the course of time they were able to acquire a broad range of modern consumer items like fashionable clothing, cell phones, radios, television, satellite dishes, bicycles and refrigerators. All of these modern items had been bought recently. One or more cars, as well as the ability of the women to afford to wear artificial hair, are the strongest and most visible indicators of wealth.

\section{The qualitative side of consumption inequalities and social stratification}

Quantitative results presented so far clearly show that the internal situation of households in rural areas is highly stratified. In the following section we will complement these data with a qualitative vignette-like description of two household economies adjacent to each other in order to unmask the characteristics of the individuals within households with regard to roles, power, age and gender. A special focus is placed 


\section{Expense types and frequencies (own sample $n=13$ )}

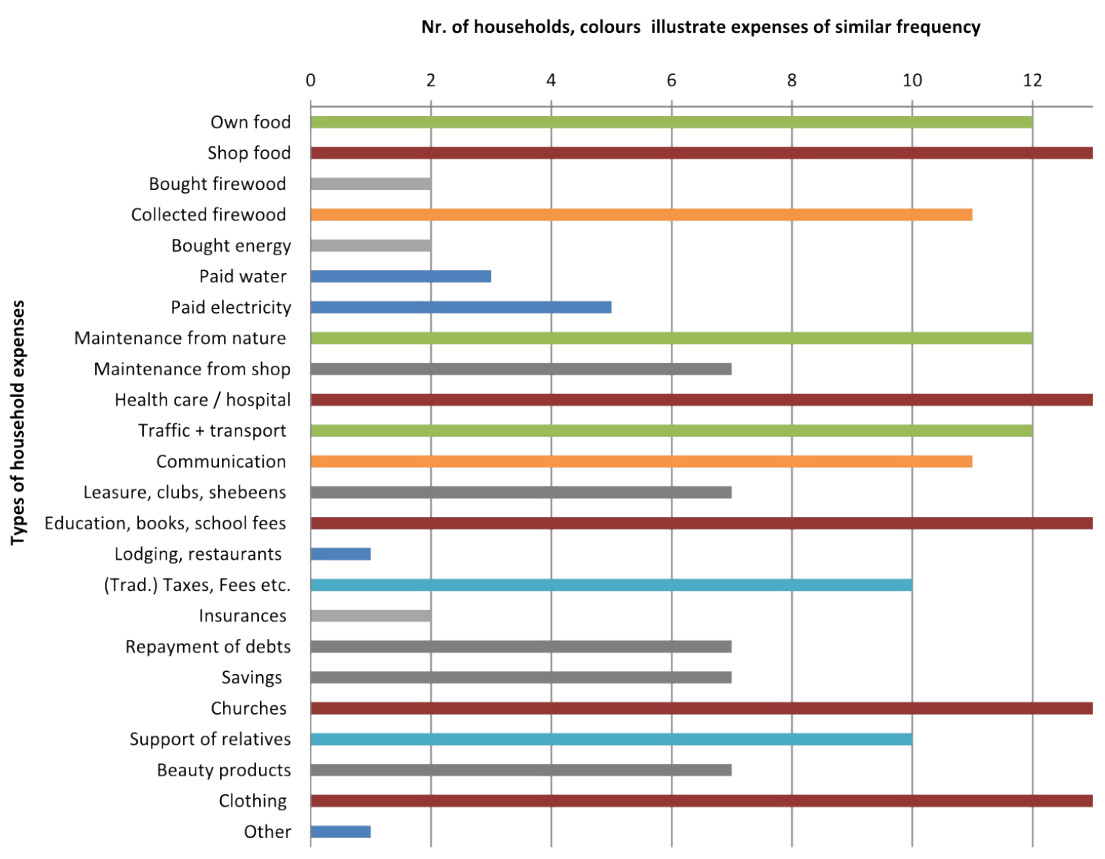

Fig. 6: Expense types and frequencies.

on diet, another factor that distinguishes households and which has not been highlighted thus far.

Elisabeth M. ${ }^{14}$, who used to earn a state salary for several decades, owns a shop in the centre of a village. The shop has electricity and a refrigerator to cool beverages including alcohol. She receives a state pension and owns a farm in the remote hinterland where paid family members herd her 30 heads of cattle and 20 heads of goats. All her grown-up children have received a higher education and ventured into the labour market, supporting her financially. The larger conglomerate of her household consists of 11 buildings, three of them made of stone, with glass windows and wooden doors, all of them are equipped with Western-style beds. The household of 16 members owns five cars, 12 cell phones, a television set with satellite dish, and several bank accounts. Some of her daughters and nieces wear expensive artificial hairstyles, made with hair imported from India or Brazil. The daily diet in her house is diverse. Breakfasts usually consist of bread, eggs and cold meat plus coffee. A warm lunch and dinner with the traditional millet or maize staple porridge and a balanced mixture of fish and meats from the supermarket is the rule. Shopping trips to town, a distance of $50 \mathrm{~km}$, happen every few days.

${ }^{14}$ All Names are Pseudonyms.
Elisabeth is one of a few lucky household heads who were able to accumulate wealth during colonial and postcolonial times. Her level of consumption is far above the majority of urban households and she is not vulnerable to undernourishment and enjoys a high social status.

Maurus M. is one of her neighbours. $\mathrm{He}$, his wife and two sons mainly depend on subsistence, casual work (stigwerk ${ }^{15}$ ) and fishing, as well as collecting and selling resources like reeds, fruits and wild vegetables. They live in a homestead of three clay huts without electricity. Maurus' household owns two heads of cattle, one Western-style bed, several tools and a plough. There are no electronic devices at all. Their lack of a cell phone is especially shameful to them, as this device has become one of the most important status symbols. Their daily diet is less diverse. They usually do not eat breakfast, but drink water or a nonalcoholic sugared millet drink. They also depend on millet or maize porridge which for three quarters of the month is accompanied by vegetables like cabbage or self-caught river-fish. Meat is a rare exception, as are shopping trips to town. Their situation provides little upward mobility since their cattle are their key resource, to be held for timely preparation of fields and good harvests. Like many

${ }^{15} \mathrm{~A}$ one-day public local work gathering that is aid in cash or in kind on the spot. A other poor people Maurus is vulnerable, and worries about the future of his children and about health problems. $\mathrm{He}$ and his wife have a strong tendency to drown their sorrows in nutritious but addictive home-brewed alcohol.

Such descriptions already indicate that households are cooperative clusters with internally stratified roles and power relations differing according to age and gender. Households consist of individuals who cooperate and are connected mainly by kinship. Household members live and feed off the common household economy and contribute shares of their labour to that common economy. The main decision-makers within households are the household heads and elders. In the past they were responsible for strategic decisions like cropping styles and dates, livestock trade, the education of the younger generation, cooperation in village and regional institutions, the fostering of social networks and family traditions and ensuring appropriate reactions to diseases and misfortune. Households' functionality and supply with goods largely depend on their skills and devotion. Respect for the elders and obedience to their orders has traditionally been strongly enforced. Household heads may be male or female, and distribute gender-specific labour tasks like herding, helping in the house or fieldwork to the younger generation. In various cases it was observed how individual actors were exchanged between rural and riverside/urban households according to the actual needs (Pröpper 2009).

Nevertheless, individuals increasingly also pursue their own strategies to fulfil their desires or choose their own pathways. Hunting decisions, the logging of a certain tree, the application of a certain herb for healing a disease, the cutting and marketing of bundles of grass, the decision to migrate to Windhoek to search for labour, the decision to sell a goat to purchase a cell phone, or the decision to leave a spouse who is drinking and start a new life at another village, are in the end made by individuals. Particularly as the younger generation come into contact with new media and regularly travel to town, which tempts with all the products of modern consumerism, household members reaching adulthood experience conflict between new needs and wishes and the demands of a traditional subsistence economy. Within households, as the locus for cultural socialization and economic survival, individual actors' needs and 
decisions must also be given due consideration in order to understand the complex fabric of domestic economy (Pröpper 2008, 2009).

Not only roles, abilities and tasks, but aspirations and desires too differ individually and vary from generation to generation, household to household. Young people wear "gangsta" T-shirts and dream of fancy MP3 players and cell phones. A showy wristwatch or a cowboy hat is a sign of dignity and status for the elder men.

Neither Elisabeths' wealth nor Maurus' poverty are outliers, they represent the poles of a continuum that spans many different cases. These specific examples depict the breadth of stratification of a rural society. The same is true of the urban cases. Looking at the school survey one finds a similar situation, clearly biased towards the higher grade 12 education in town because fees can only be paid by people with a steady cash income. Most of our interlocutors perceived themselves as suffering from poverty and inequality. When asked what poverty means for them, within the sample of 98 students the lack of things like houses and clothes was mentioned by $50 \%$, while $30 \%$ mentioned food deprivation. 22 students described personal experiences of suffering, and voiced their hatred and dislike of poverty. When asked what wealth meant to them, again in $50 \%$ of the cases a life endowed with things and free of suffering was mentioned, exemplified by possession of sufficient cars, money and livestock. 14 students clearly voiced their appreciation of wealth and their desire and determination to become wealthy themselves.

\section{Conclusion}

Presenting ethnographic and economic data on household economies within a situation of visibly increasing consumerism, we have argued in this paper that the influx of modern goods and related incentives and desires is one transformative dimension in Kavango. In fact it is very challenging to quantify an increase in consumerism along a temporal scale. However, the qualitative data about the aspirations and stratified attempts of people like Elisabeth and Maurus and their families alike seem particularly indicative of an expanding process through which increasing numbers of people develop new desires (Belk et al.
2003, Stearns 2001) and attempt to achieve well-being (Mathews \& Izquierdo 2009) through the consumption of more objects (e.g. goods, energy, information) which are not needed for their bare subsistence (Stearns 2001). It is not only the growing population but the growing aspirations of that growing population for additional comforts and a share of the global project of modernity epitomized by new hairstyles, clothes, means of communication or foods - that we have to take into consideration as a driving force of future social and ecological developments. As we have shown, in many cases people perceive and accept various additional types of expenditure, of buying additional comfort, pleasure, and the like.

However, so far many farmers are faced with many new incentives but have few additional sources of income beyond the extraction of natural resources - a problem that we perceive may add to the willingness of the poor in particular to withdraw capital from the public account of natural resources, by attempting to market resources like e.g. thatch grass, timber, or reeds.

The ongoing market integration, visualized by people's endowment with consumer goods, has its winners, but also leaves other people behind. As we have outlined - by shedding light on household processes beyond accumulated statistics social stratification is a real problem in the Kavango society. In the SEBS we asked people how satisfied they are with their economic situation. It turned out that $80 \%$ of respondents were either totally or somewhat dissatisfied with their economic situation. One could argue that stratification is a problem in any society, however, as has been found elsewhere, it is unclear whether the developmental challenge to create formal-sector employment for larger parts of populations of southern Africa can be met at all (Department of Social Development (Committee of Inquiry into a Comprehensive System of Social Security for South Africa) 2002, Ferguson 2009). Under such circumstances our findings also function as an explanatory background for a potential marginalization and disintegration of the agrarian parts of society. Furthermore, they may help to explain the widespread salience of envy and witchcraft as drivers of peoples' choices - a phenomenon that we will analyse elsewhere.

\section{Acknowledgements}

TFO is sponsored by the German Federal Ministry of Education and Research (BMBF). We would like to acknowledge the crucial role of the following TFO researchers in collecting and processing SEBS data: Nadege Azebaze, Victoria Handimba, Joseph Kanyanga, Mathias Legler, Robert Mukuya, Oliver Mundy, Raphael Sinkumba.

We are also greatly indebted to our many interlocutors in research phases in various parts of the Kavango and in Rundu, as we are also grateful to our many TFO colleagues for their continuous support and critical discussions.

\section{References}

Belk, R.W., Ger, G., Askegaard, S. (2003): The Fire of Desire: A Multisited Inquiry into Consumer Passion. - Journal of Consumer Research 30: 326-351. CrossRef

Campbell, C. (1987): The romantic ethic and the spirit of modern consumerism. Oxford: Blackwell.

Case, K.E., Fair, R.C., Oster, S.M. (2009): Priciples of Microeconomics. 9th Edition. Upper Saddle River, NJ: Prentice Hall.

Central Intelligence Agency (CIA) (2012): The World Factbook. In: Central Intelligence Agency, CIA

Chan, K.M.A., Satterfield, T., Goldstein, J. (2012): Rethinking ecosystem services to better address and navigate cultural values. - Ecological Economics 74: 8-18. CrossRef

Daily, G.C. (1997): Nature's Services: Societal Dependence on Natural Ecosystems. Washington: Island Press.

Department of Social Development (Committee of Inquiry into a Comprehensive System of Social Security for South Africa) (2002): Transforming the Present-Protecting the Future: Report of the Committee of Inquiry into a Comprehensive System of Social Security for South Africa. In. Pretoria: Government Printer

Dobler, G. (2009): Chinese Shops and the Formation of a Chinese Expatriate Community in Namibia. - The China Quarterly 199: 707-727. CrossRef

Falk, T. (2008): Communal Farmers' Natural Resource Use and Biodiversity Preservation. A New Institutional Economic Analysis from Case Studies in Namibia and South Africa. Göttingen: Cuvilier Verlag.

Ferguson, J. (2009): The Uses of Neoliberalism. - Antipode 41: 166-184. CrossRef 
Fisch, M. (1999): History of the female chiefs of the Shambyu tribe (Kavangoland). - Journal Namibia Wissenschaftliche Gesellschaft 47: 109-120.

Fisch, M. (2005): The Mbukushu in Angola. A History of Migration, Flight and Royal Rainmaking. Köln: Köppe Verlag.

Fumanti, M. (2002): Small town élites in northern Namibia - the complexity of class formation in practice. - In: Winterfeldt, V., Fox, T., Mufune, P. [Eds.]: Namibia. Society. Sociology (pp. 169-177). Windhoek: Department of Sociology. University of Namibia.

Greiner, C. (2008): Zwischen Ziegenkraal und Township: Migrationsprozesse in Nordwestnamibia. Berlin: Reimer.

Gröngröft, A., Luther-Mosebach, J. (2012): TFO: Draft Report on the Yield Assessment Campaign 2012. In. Hamburg: Institute of Soil Science

Hahn, H.P. [Ed.] (2008): Consumption in Africa. Anthropological Perspectives. Münster: Lit.

Henry, J., Macbeth, H. (2004): Studying Food Intake Frequency. A Macrosurvey Technique for Anthropologists. - In: Macbeth, H., MacClancy, J. [Eds.]: Researching food habits. Methods and Problems (pp. 135-148). New York: Berghahn.

Hinz, M.O. (2010): The Shambyu Traditional Authority. - In: Hinz, M.O [Ed.]: Customary law ascertained. Windhoek: Namibia Scientific Society.

Isaacs, D. (2012): Nam Gini-Coefficient now 0.59. In, The Nambian Sun Windhoek: The Nambian Sun online. http://www.namibiansun.com/content/bu siness/nam-gini-coefficient-now-059. accessed 19.02.2013

Kapaana, P. (2007): Commercial land reforms in postcolonial Namibia. What happened to liberation struggle rhetoric? - In: Melber, H. [Ed.]: Transitions in Namibia. Which Changes for Whom? (pp. 32-49). Uppsala: Nordiska Afrikainstitutet.

Kaundu, A.M. (2002): Republic of Namibia. Mbunza Traditional Authority. Decision of Customary Law Court Fines. Kapako: Paper-Copy.

Likuwa, K. (2001): Djwaini - A coffin with your recruit number on. The experience of contract migrant labourers from Kavango to South African Gold Mines 1944-1977. - BE Thesis in History, UNAM.

Mathews, G., Izquierdo, C. [Eds.] (2009): Pursuits of happiness: well-being in anthropological perspective. - New York: Berghahn Books.

Mendelsohn, J., el Obeid, S. (2003): Sand and Water. A profile of the Kavango Region. Cape Town: Struik.

Mendelsohn, J., el Obeid, S. (2004): Okavango River. The flow of a lifeline. Cape Town: Struik
Miller, D. (2012): Consumption and its Consequences. Cambridge: Polity Press.

Namibia Statistics Agency (2012a): Namibia Household Income and Expenditure Survey 2009/2010. Windhoek: Namibia Statistics Agency.

Namibia Statistics Agency (2012b). Poverty Dynamics in Namibia. A comparative study using the 1993/94, $2003 / 04$ and the 2009/10 NHIES surveys. In. Windhoek: Namibia Statistics Agency

National Planning Commission (2003): 2001 Population and Housing Census. National Report. Basic Analysis with Highlights. Windhoek: NPC - Central Bureau of Statistics.

National Planning Commission (2003/2004): Namibia Household income and Expenditure Survey 2003/2004. Windhoek: Rebublik of Namibia, RoN.

National Planning Commission (2010): Namibia National Household Income and Expenditure Survey 2009/2010 Preliminary Results. Windhoek: Republic of Namibia, RoN.

National Planning Commission (2012): Namibia 2011 Population and Housing Census Preliminary Results. Windhoek: Republic of Namibia, RoN.

Princen, T., Maniates, M., Conca, K. (2002): Confronting Consumption. - In: Princen, T., Maniates, M., Conca, K. [Eds.]: Confronting Consumption (pp. 1-20). Cambridge: The MIT Press.

Pröpper, M. (2008): Trust, Sharing and Cooperation in the Central Kavango Region, North-East Namibia. Linking the Results of Experimental Economics with Ethnographic Research. - In: Limpricht, C., Biesele, M. [Eds.]: Heritage and Cultures in Modern Namibia. In-depth Views of the Country. A TUCSINFestschrift (pp. 64-77). Windhoek/ Göttingen: Klaus Hess Publishers.

Pröpper, M. (2009): Culture and biodiversity in central Kavango, Namibia. Berlin: Reimer.

Pröpper, M., Gröngröft, A., Falk, T., Eschenbach, A., Fox, T., Gessner, U., Hecht, J., Hinz, M.O., Huettich, C., Hurek, T., Kangombe, F., Keil, M., Kirk, M., Mapaure, C., Mills, A., Mukuya, R., Namwoonde, E., Overmann, J., Petersen, A., Reinhold-Hurek, B., Schneiderat, U., Strohbach, B.J., LuckVogel, M., Wisch, U. (2010): Causes and perspectives of land-cover change through expanding cultivation in Kavango. - In: Hoffman, T.M., Schmiedel, U., Jürgens, N. [Eds.]: Biodiversity in Southern Africa. Implications for Landuse and Management (pp. 1-31). Göttingen/ Windhoek: Klaus Hess Publishers.

Republic of Namibia (2002): Communal Land Reform Act (5 of 2002). Windhoek: Government Gazette No. 137.
Republic of Namibia (2004): Namibia Vision 2030. Windhoek: Office of the President.

Saunders, P. (1990): Social Class and Stratification. London: Routledge.

Sikerete, E. (2006). The Laws of the Shambyu Community. In. Rundu: Council of the Shambyu Traditional Authority

Stearns, P.N. (2001): Consumerism in World History. The Global Transformation of Desire. London: Routledge.

Steinmann, D. (2004). Cattle breeders are a clever species. In, Economist (pp. http://www.economist.com.na/2003/202 1nov/2011-2021-2003.htm access: 2025.2008.2004). Windhoek

Vissers, E. (1997): Alcohol Use and Abuse in the Kavango of Namibia. - MA, Universiteit van Utrecht.

Weber, M. (1964): Wirtschaft und Gesellschaft: Grundriss der verstehenden Soziologie. Köln: Kiepenheuer \& Witsch.

Weber, M. (2010): The distribution of power within the community: Classes, Stände, Parties. - Journal of Classical Sociology 10(2): 137-152. CrossRef

Wilk, R. (1998): Emulation, Imitation, and Global Consumerism. - Organization Environment 11: 314-333. CrossRef

Wilk, R. (2006): The Ecology of Global Consumer Culture. - In: Haenn, N., Wilk, R. [Eds.]: The environment in anthropology. A reader in ecology, culture, and sustainable living (pp. 418-429). New York: New York University Press.

\section{Affiliations}

Michael Pröpper*

(michael.proepper@uni-hamburg.de), Institute for Social and Cultural Anthropology, University of Hamburg Edmund-Siemers-Allee 1

20146 Hamburg, GERMANY

Thomas Falk

(falkt@staff.uni-marburg.de)

Institute for Cooperation in Developing Countries, Philipps-University Marburg Am Plan 2

35032 Marburg, GERMANY

Stephanie Domptail,

(stephanie.domptail@agrar.unigiessen.de), Benjamin Kowalski (benjamin.kowalski@agrar.unigiessen.de)

Institute for Agricultural Policy and Market Research, University of Giessen Senckenbergstrasse 3 35390 Giessen, GERMANY 
Laura Marlene Große

(laura.grosse@wiwi.uni-marburg.de)

Faculty of Business Administration and

Economics, Macroeconomics, Philipps-

University Marburg

Universitätsstraße 2435032 Marburg,

GERMANY

*Corresponding author 
